\title{
Effect of Broiler Crating Density and Transportation Distance on Preslaughter Losses and Physiological Response During the Winter Season in Punjab, Pakistan
}

-Author(s)

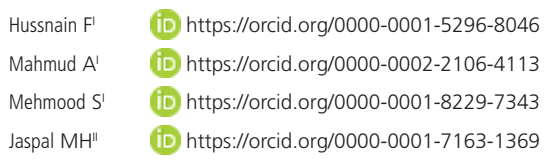

Department of Poultry Production, University of Veterinary and Animal Sciences, Lahore, Pakistan.

Department of Meat Science and Technology, University of Veterinary and Animal Sciences, Lahore, Pakistan

\section{-Mail Address}

Corresponding author e-mail address Faisal Hussnain

Department of Poultry Production, University of Veterinary and Animal Sciences, Lahore, Pakistan.

Phone: +92 3014674474

Email: Faisal.hussnain@uvas.edu.pk

\section{ABSTRACT}

A study was conducted to determine the impact of crating density and transportation distance on losses and physiological response of broilers during the winter season. For this, ROSS-308 broilers were crated at three densities (i.e., 10, 12, and 15 birds/crate) in plastic crates and transported in three distances (i.e., 80, 160, and $240 \mathrm{~km}$ ) during the winter season at $3.6-9.5^{\circ} \mathrm{C}$ temperature and $63.3-78.8 \%$ relative humidity. Results showed that body weight loss increased significantly with the increase in transportation distance and decrease in crating density, whereas dead on arrival, physical injuries and bruises were not different among different transportation distance and crating density treatments. Significant reduction in carcass and breast yield was observed with the increase in transportation distance, whereas an increase in crating density above 12 birds per crate increased breast yield. Birds transported for $240 \mathrm{~km}$ had the highest serum catalase activity and the lowest rectal body temperature compared to other treatments. A gradual increase in crating density resulted in the increase in thyroxine concentration and reduction in rectal temperature. Serum glucose, albumin and uric acid concertation increased significantly after $160 \mathrm{~km}$ of transportation, but serum triglyceride contents decreased. Moreover, an increase in crating density also increased serum glucose and triglyceride. Results suggested that longer transportation distance during the winter season increased body weight shrinkage with a reduction in carcass and breast yield, and the impact of losses and stress was greater in treatments having a lower number of birds in crates.

\section{INTRODUCTION}

The journey of broilers from farms to the processing plant, after a relatively comfortable environment of a poultry house, is associated with multi-dimensional stressors (Gregory, 2010). Genetic improvements have enabled broiler to gain maximum weight at a relatively shorter time, but it also increased the sensitivity of the birds particularly for thermal variations (Burkholder et al., 2008). The transportation of broilers has been reported to induce immediate stress in swine and poultry and the reaction of the animal to stress is dependent on the duration and intensity of the stress, their physiological status, and environment after stress (Brown et al., 1998; Fazio \& Ferlazzo, 2003). In the case of transportation stress, the intensity of stress depends on environment during transportation, length of transportation journey and duration of the bird being inside the crates (Yalçin et al., 2004). In broiler, heat stress has always been a point of concern for the producers, but considerable data reveals that the cold stress is equally detrimental for the health and welfare of poultry (Aarif et al., 2013; Phuong et al., 2016). Transportation at low environmental temperature can cause hypothermia and can affect performance and welfare of broilers 
(Warriss et al., 2005; Qi et al., 2017). The cold stress has been reported to activate the hypothalamic-pituitarythyroid axis of the bird and increases corticosterone and cortisol concentration (Aarif et al., 2013; Slota et al., 2015).

The stress associated with transportation can cause dead-on-arrival (DOA) in broilers depending on transportation distance and ambient temperature (Elsayed, 2014). Contrarily, Vošmerová et al. (2010) reported more stress in short distance transported birds due to the lack of post crating recovery period. While Silva et al. (2011) did not find any effect of short distance transportation (up to $57 \mathrm{~km}$ ) during the winter season on DOA. Not only mortality but an increase in the length of journey has been reported to increase body weight loss along with a significant increase in injuries, broken wings, and condemn carcass percentage and a decrease in the proportion of carcass cut up organs in broilers (Moran \& Bilgili, 1995; Carlyle et al., 1997; Bianchi et al., 2005).

Broilers are usually transported to processing plants in loose crates and trucks without any environment control system. Welfare concerns arises with this system as the birds suddenly shifts from the nearly ideal environment of poultry farm to environmental extremes without proper protection (Weeks, 2014). The lack of controlled ventilation in open trucks hinders air flow and lead to building different temperature zones within a truck (Knezacek et al., 2010). Crating density can by hypothesized as the major factor determining the microclimate of the vehicle and its effect varies with the length of journey in different seasons (Whiting et al., 2007). Data regarding the effect of crating density on pre-slaughter losses is scarce. A few studies conducted regarding the effect of crating density has been associated with the changes in physiological response (Delezie et al., 2007; Vieira et al., 2013). So, crating density, in countries where winter temperature is low, need to be optimized. Since transportation stress cannot be eliminated in poultry production, therefore, the study was planned with the objective to assess preslaughter losses and physiological response in broilers at different transportation distances under different crating densities in the winter season.

\section{MATERIALS AND METHODS}

\section{Birds and their treatments}

The experiment was conducted at the Department of Poultry Production, University of Veterinary and Animal Sciences (UVAS), Lahore, Pakistan. In this experiment, ROSS-308 broilers (straight run, body weight 1900 - 2050g, age: 35 days) were picked at random from a commercial broiler farm after 4 hours of feed withdrawal before catching. The birds were separated into nine treatment groups (03 distances $\times 03$ crating densities). Transportation distance was categorized as short $(80 \mathrm{~km})$, medium $(160 \mathrm{~km})$, and long $(240 \mathrm{~km})$ under three crating densities: Low $=10$ birds $\left(0.050 \mathrm{~m}^{2} /\right.$ bird$)$, Medium $=12$ birds $\left(0.042 \mathrm{~m}^{2} /\right.$ bird), and high $=15$ birds $\left(0.033 \mathrm{~m}^{2} /\right.$ bird $)$ per crate. To reduce the effect of the truck microenvironment, each treatment was replicated 10 times with individually tagged birds in each crate placed at various locations in the truck. The birds were transported in commercial trucks (capacity 144 crates) carrying different crating densities in loose plastic crates (Engi Plastic Industries Pvt. Ltd., Sundar, Pakistan) having the dimensions of $0.91 \mathrm{~m}$ (length) $\times 0.55 \mathrm{~m}$ (width) $\times 0.31 \mathrm{~m}$ (height) at an average speed of $45-50 \mathrm{~km} / \mathrm{h}$ during late night early morning. The experimental birds were weighed and tagged on shanks before being placed in the crates. During growing phase, the birds were placed on litter floor (rice husk) in environmentally controlled commercial broiler farms $\left(0.06 \mathrm{~m}^{2} / \mathrm{bird}\right)$ under standard temperature and relative humidity conditions. The birds were fed with ad-libitum diets (strain specific broiler ration) and fresh water and light was available for $24 \mathrm{~h}$. All the procedures and bird handling protocols were used according to guidelines and standards after approval from the Ethical Review Committee of UVAS, Lahore (Approval No: DR/916-2017).

\section{Climatic indices}

The experiment was conducted during the winter season and the birds were transported in the vicinity of the districts of Kasur and Lahore, Punjab, Pakistan. The temperature and relative humidity were recorded with the help of a digital weather tracker (Kestrel 4500 NV, Nielsen-Kellerman, USA). The range of temperature and relative humidity measured at various distances and time ranged from $3.6-9.5^{\circ} \mathrm{C}$ and $63.3-78.8 \%$, respectively. During the journey, there were patches of mild to severe fog at several places. The journeys to be traveled were of $240 \mathrm{~km}, 160 \mathrm{~km}$, and $80 \mathrm{~km}$ and started at 12:25 AM, 02:45 AM, and 04:30 AM, respectively, and all the trucks reached the slaughtering facility at almost 07:00 AM.

\section{Parameters studied}

\section{Transportation losses}

Body weight loss (\%) during the transportation was measured as the difference in bird weight at 
the farm ( $\mathrm{g}$ ) and final body weight ( $\mathrm{g}$ ) measured at the ultimate destination. The dead-on-arrival (DOA) percentage for each group was calculated by dividing the number of birds found dead by the total of birds in the experimental crates. To calculate physical injuries (\%), every single bird from each crate was observed and physical injuries (if any) were recorded and the proportion was calculated from total birds. Similarly, bruises on wings, breast, and legs (if any) were visibly observed and their proportion with the total number of birds slaughtered per replicate was calculated.

On arrival at the slaughtering facility, 3 tagged birds from each replicate were randomly picked and slaughtered manually with a knife. After bleeding, the birds were defeathered and eviscerated. Dressing (\%) was calculated as hot carcass with neck and without giblets. The percentage of abdominal fat pad was calculated as weight abdominal fat relative to live body weight (g) while breast (\%) was calculated relative to carcass weight.

\section{Physiological Response}

On arrival at the slaughtering facility, rectal body temperature was recorded randomly from each treatment with the help of digital thermometer (NB-100, Ossmax, Germany). The tagged birds were separated from the other birds weighed and slaughtered manually. To reduce the effect of stay before slaughtering, all the birds were divided into 6 slaughtering stations and all treatments were slaughtered at same time randomly. The blood was collected from the jugular vein of 10 birds from each treatment in plain vacutainers. Vacutainers were then centrifuged for 10 minutes at $3000 \mathrm{rpm}$ and serum was carefully separated with a sterilized pipette into labeled Eppendorf tubes. Serum samples were stored at $-20{ }^{\circ} \mathrm{C}$ for later blood biochemical analysis. The samples were maintained at $3-8^{\circ} \mathrm{C}$ while handling.

The estimation of serum triiodothyronine (T3), and thyroxine (T4) were made using the enzyme immune assay test kit of BioCheck, Inc. (Catalog \#: BC-1005 and BC-1007). Whilst, the Cortisol was measured with the help of ELISA Kit of Calbiotech Inc. (Catalog \#C0103S). The catalase activity was estimated using the methodology of Hadwan \& Abed (2016). Briefly, 4 test tubes (sample, control test, standard and blank) were prepared. The sample tube contained $100 \mu \mathrm{l}$ serum and $1000 \mu \mathrm{l}$ hydrogen peroxide $(20 \mathrm{mM})$, the control test tube contained $100 \mu \mathrm{l}$ serum and 1000 $\mu \mathrm{l}$ distilled water, the standard tube contained $100 \mu \mathrm{l}$ distilled water and $1000 \mu$ l hydrogen peroxide, and the blank contained $1100 \mu$ listilled water. All these tubes were vortexed and incubated at $37^{\circ} \mathrm{C}$ for $3 \mathrm{~min}$, after that $4000 \mu \mathrm{l}$ ammonium molybdate $(32.4 \mathrm{mmol} / \mathrm{l})$ was added to stop the reaction. Later changes in absorbance were recorded at $374 \mathrm{~nm}$ against the reagent blank.

The samples were analyzed for serum total proteins $(\mathrm{g} / \mathrm{dL})$ and albumin $(\mathrm{g} / \mathrm{dL})$ contents using immunoassay kit of Tron ${ }^{\circledR}$ (3-4 Rue De Montolembert, Paris, France); while serum glucose $(\mathrm{mg} / \mathrm{dL})$, triglycerides $(\mathrm{mg} / \mathrm{dL})$, and uric acid $\left(\mathrm{mg} / \mathrm{dL}\right.$ ) were analyzed using Human ${ }^{\circledR}$ (Human Gesellschaft für Biochemia und Diagnostica $\mathrm{mbH}$, Wiesbaden, Germany) kits with spectrophotometer (UVNIS Spectrophotometer AMV 09 Tlead Int. Co. Ltd., Qingdao, Shangdong, China) at kit recommend wavelength.

\section{Statistical analysis}

The data collected were analyzed by two-way analysis of variance (ANOVA) technique under Completely Randomized Design assuming transportation distance and crating density as the main effect. The significant means were separated using Tukey's HSD test (Tukey, 1953), considering significance level at $p \leq 0.05$, with the help of SAS 9.4 (SAS Institute, 2013).

\section{RESULTS AND DISCUSSION}

Transportation of animals is a necessary step in meat processing value chain. Along with other preslaughter handling factors, however, transportation can impact bird welfare and, in some cases, lead to economic losses (Vieira et al., 2011). There was a significant increase in BWL (\%) with the increase in transportation distance (Table 1). The average BWL (\%) in broilers traveled for 80,160 , and $240 \mathrm{~km}$ was $1.99,2.55$, and $3.65 \%$, respectively. Longer transportation times are associated with longer fasting periods in broilers (Savenije et al., 2002; Delezie et al., 2007) and higher exposure to stressful conditions especially in terms of thermal variations, crating, acceleration, vibration, noise, feed and water deprivation and social disruption (Kannan et al., 1997; Mitchell \& Kettlewell, 1998; Fletcher, 2002). Similarly, Bianchi et al. (2005) investigated the effect of broiler transportation for $\leq 3.5 \mathrm{~h}, 3.5-5 \mathrm{~h},>5 \mathrm{~h}$ in Bologna, Italy from September 2002 to May 2003 (321 flocks) and reported 0.24, 0.41, 0.45\% BWL. The study reported an average BWL of 321 flocks, so, the BWL in that study was relatively lower than in the present study, moreover, higher BWL in the present study could be associated with the lower temperature than the previous study, poor road conditions, differences in the length of transportation and differences in the 
Table 1 - Live bird losses and carcass yield as affected by transportation distance and crating density.

\begin{tabular}{|c|c|c|c|c|c|c|c|}
\hline Treatments & BWL (\%) & DOA (\%) & Breast bruises (\%) & Wing bruises (\%) & Carcass (\%) & Breast (\%) & Abdominal Fat (\%) \\
\hline & \multicolumn{7}{|c|}{ Transportation Distance (Km) } \\
\hline $80 \mathrm{~km}$ & $1.99 \pm 0.12^{c}$ & $0.00 \pm 0.00$ & $2.22 \pm 1.54$ & $0.00 \pm 0.00$ & $65.40 \pm 0.11^{\mathrm{a}}$ & $28.79 \pm 0.32^{a}$ & $1.83 \pm 0.08$ \\
\hline $160 \mathrm{~km}$ & $2.55 \pm 0.14^{b}$ & $0.33 \pm 0.33$ & $3.33 \pm 1.86$ & $1.11 \pm 1.11$ & $64.77 \pm 0.10^{b}$ & $28.32 \pm 0.37^{\mathrm{ab}}$ & $1.72 \pm 0.10$ \\
\hline \multirow[t]{2}{*}{$240 \mathrm{~km}$} & $3.65 \pm 0.13^{a}$ & $0.94 \pm 0.53$ & $6.67 \pm 2.48$ & $3.33 \pm 1.86$ & $64.20 \pm 0.13^{c}$ & $27.51 \pm 0.32^{b}$ & $1.60 \pm 0.07$ \\
\hline & \multicolumn{7}{|c|}{ Crating densities (birds/crate) } \\
\hline Low & $3.24 \pm 0.15^{a}$ & $1.00 \pm 0.56$ & $6.67 \pm 2.48$ & $3.33 \pm 1.86$ & $64.94 \pm 0.13$ & $27.40 \pm 0.33^{b}$ & $1.65 \pm 0.11$ \\
\hline Medium & $2.96 \pm 0.14^{\mathrm{a}}$ & $0.28 \pm 0.28$ & $4.44 \pm 2.10$ & $1.11 \pm 1.11$ & $64.75 \pm 0.11$ & $28.25 \pm 0.31^{\mathrm{ab}}$ & $1.76 \pm 0.07$ \\
\hline \multirow[t]{2}{*}{ High } & $1.98 \pm 0.12^{b}$ & $0.00 \pm 0.00$ & $1.11 \pm 1.11$ & $0.00 \pm 0.00$ & $64.69 \pm 0.13$ & $28.97 \pm 0.36^{a}$ & $1.74 \pm 0.08$ \\
\hline & \multicolumn{7}{|c|}{$p$-value } \\
\hline Distance & $<0.0001$ & 0.1754 & 0.2742 & 0.1634 & $<0.0001$ & 0.0220 & 0.1591 \\
\hline Density & $<0.0001$ & 0.1326 & 0.1230 & 0.1634 & 0.2516 & 0.0040 & 0.6132 \\
\hline Interaction & 0.0974 & 0.5915 & 0.9818 & 0.6204 & $<0.0001$ & 0.3971 & 0.5331 \\
\hline
\end{tabular}

a-c Means in a column with no common superscript differ significantly at $p \leq 0.05$.

'Values are least square mean \pm standard error.

BWL: Body weight loss; DOA: Dead on arrival

Crating density: Low $=10$ birds/crate $\left(0.050 \mathrm{~m}^{2} /\right.$ bird $), 12$ birds $/ \mathrm{crate}\left(0.042 \mathrm{~m}^{2} / \mathrm{bird}\right)$, and 15 birds $/ \mathrm{crate}\left(0.033 \mathrm{~m}^{2} / \mathrm{bird}\right)$

crating densities in both studies. BWL (\%) remained comparable $(p>0.05)$ in birds transported at low and medium crating density, while a significant decrease in BWL (\%) was observed in birds transported at high crating densities (15 birds/crate) compared to other treatments. Higher BWL (\%) in birds crated at lower crating densities (i.e., 10 birds per crate) could be attributed to relatively higher struggle and enhanced metabolic activity to cope with lower environmental temperature (Dadgar et al., 2012). Other groups, however, have demonstrated that more birds in a crate generated enough metabolic heat that they survived better in Canadian winter temperatures of $-5,-10$, and $-15^{\circ} \mathrm{C}$ (Strawford et al., 2011).

No differences in dead on arrival (DOA) and bruising percentage (breast and wing bruises) were observed among different transportation distance and crating density treatments (Table 1). These findings suggested that the stress associated with winter transportation was bearable by the birds. The birds transported for $240 \mathrm{~km}$ or those transported at low crating densities (10 birds per crate) showed 0.94 and $1 \% \mathrm{DOA}$, respectively; but the differences were not significant ( $p>0.05)$ among different treatments (Table 1). However, these little margins can result in significant variations in terms of profit margin. In accordance, Silva et al. (2011) reported no effect of $57 \mathrm{~km}$ transportation on DOA (\%) during the winter season in Londrina, Brazil, while Chauvin et al. (2011) also reported no effect of transportation on mortality rates in France at an average $13^{\circ} \mathrm{C}$ temperature. High mortality in birds transported at low crating density suggested that the DOA during the winter season was more associated with the chilling effect in birds, produced due to hypothermia, in trucks having lower number of birds per crate (Watts et al., 2011). Similarly, another study reported that mortality at very low ambient temperature (below $-14^{\circ} \mathrm{C}$ ) was higher if the birds were placed at low $\left(<40 \mathrm{~kg} / \mathrm{m}^{2}\right)$ crating density as compared to the birds at higher $\left(40-45 \mathrm{~kg} / \mathrm{m}^{2}\right)$ crating density in Canada (Caffrey et al., 2017). Fewer birds per crate translate to more space for birds, which could result in relatively higher chances of bruising and injuries during jerks and jolts of transportation (Elrom, 2000). The bruising (\%) in the present study remained comparable to that of Jacobs et al. (2017), who reported $3.65 \%$ bruised breast and wings and $1.38 \%$ bruised leg in birds after transportation. However, some studies also reported bruises \% ranges from 0.022 to $25 \%$ in broilers (Farsaie et al., 1983; Ekstrand, 1998).

Broilers transported for $80 \mathrm{~km}$ had the highest carcass and breast (\%) while significant reduction was observed with each level increase in transportation distance (Table 1). Similarly, breast (\%) was increased significantly with the increase in crating density but abdominal fat (\%) was neither affected ( $p>0.05)$ by different transportation distance nor by different crating densities (Table 1). A higher dressed carcass (\%) in birds transported for short distances and subsequent decrease with the increase in transportation distance could be due to a reduction in the share of viscera and other inedible portions for $80 \mathrm{~km}$ traveling (Table 1). Kim et al. (2007) reported a significant decrease in the share of small intestine after 3 hours of feed withdrawal. Similarly, in the $80 \mathrm{~km}$ treatments, to cope with the cold environment the metabolism gets faster and resulted in faster emptying of the intestine as compared to the rest of the treatments; thereby, increasing the relative share of the dressed carcass. While 
the further reduction in carcass (\%) with an increase in distance could possibly be attributed to shrinkage of the carcass as the birds were feed 4 hours before catching and up till slaughtering the total withdrawal time reached to $8-11.5$ hours. In accordance, Kim et al. (2007) also reported a significant decrease in carcass yield after 6 hours of the feed withdrawal period. Similarly, Mazanowski (1997) also reported a significant decrease in carcass weight when weight loss during transportation exceeds $3 \%$ and weight loss in the present study for broiler transported for 160 and $240 \mathrm{~km}$ were 2.55 , and $3.65 \%$, respectively. Although the percentage of different losses during transportation was less; these small values can combine to cause severe economic losses to the processor as well as severely affect animal welfare (Ali et al., 2008; Chauvin et al., 2011). Data regarding the effect of crating density on carcass characteristics is scarce and no study has been reported on this aspect.

Rectal body temperature was found to be higher in birds transported for 80 and $160 \mathrm{~km}$ while a significant decrease was observed when transportation distance increased up to $240 \mathrm{~km}$ (Table 2). The finding could be associated with relative decrease in the rate of metabolism with the length of the journey and the increase in fasting period (Delezie et al., 2007). Broilers with slower metabolism were unable to regulate their body temperature, particularly those subjected to prolonged exposure (as in longer transportation) to a low ambient temperature of up to $-18^{\circ} \mathrm{C}$ (Watts et al., 2011). Similarly, Hunter et al. (1999) reported $2.1^{\circ} \mathrm{C}$ and $10^{\circ} \mathrm{C}$ drop in rectal temperature of the birds exposed to $12^{\circ} \mathrm{C}$ and from 0 to $4^{\circ} \mathrm{C}$ ambient temperature during transportation. Accordingly, Dadgar et al.
(2012) reported a decrease in body temperature in birds exposed to low ambient temperature (i.e. -15, $-12,-9$, and $+22{ }^{\circ} \mathrm{C}$ ). Results also showed that the crating of broilers at high crating density (15 birds per crate) resulted in higher rectal temperature compared to those transported at low and medium crating densities (Table 2). Similar findings were also previously reported by Delezie et al. (2007), but the study was conducted during the hot season and no such study was previously conducted during the winter season.

Results regarding physiological response showed that broiler transportation during the winter season did not affect ( $p>0.05)$ serum triiodothyronine (T3) and serum thyroxine (T4) contents (Table 2). Whereas, a significant $(p<0.05)$ increase in serum catalase concentration was observed in the broilers transported for $240 \mathrm{~km}$ as compared to other treatments (i.e., 80 and $160 \mathrm{~km}$ ). Similarly, serum T3 and catalase contents were not affected by different crating densities, but serum T4 concentration decreased significantly $(p<0.05)$ with the increase in crating density (Table 2$)$. Catalase is an antioxidant enzyme, and its activity is a measure to assess the oxidative stress on the living organism (Cadenas \& Davies, 2000). Higher catalase activity in longer transported broilers could be due to increase in production of free radicals in birds subjected to longer stress periods (Ismail et al., 2013). No study has been conducted till date regarding serum catalase activity in response to transportation distance and crating densities. Similarly, Doktor \& Połtowicz (2009) reported no effect of broiler transportation on T3 concentration compared to non-transported birds. Different crating densities had significant differences in T4 contents, while T3 contents and catalase activity

Table 2 - Physiological response and blood metabolites under the influence of transportation distance and crating densities.

\begin{tabular}{|c|c|c|c|c|c|c|c|c|c|}
\hline Treatments & $\begin{array}{c}\text { Rectal temp. } \\
\left({ }^{\circ} \mathrm{F}\right)\end{array}$ & $\begin{array}{c}\mathrm{T} 3 \\
(\mathrm{ng} / \mathrm{mL}) \\
\end{array}$ & $\begin{array}{c}\mathrm{T} 4 \\
(\mu \mathrm{g} / \mathrm{dL})\end{array}$ & $\begin{array}{c}\text { Catalase } \\
(\mathrm{kU} / \mathrm{L})\end{array}$ & $\begin{array}{l}\text { Glucose } \\
\text { (mg/dL) }\end{array}$ & $\begin{array}{c}\text { Total Protein } \\
(\mathrm{g} / \mathrm{dL})\end{array}$ & $\begin{array}{l}\text { Albumin } \\
(\mathrm{g} / \mathrm{dL})\end{array}$ & $\begin{array}{l}\text { Uric Acid } \\
\text { (mg/dL) }\end{array}$ & $\begin{array}{c}\text { Triglyceride } \\
(\mathrm{mg} / \mathrm{dL})\end{array}$ \\
\hline \multicolumn{10}{|c|}{ Transportation distance $(\mathrm{km})$} \\
\hline $80 \mathrm{~km}$ & $105.19 \pm 0.11^{\mathrm{a}}$ & $3.29 \pm 0.30$ & $3.17 \pm 0.12$ & $0.08 \pm 0.010^{b}$ & $189.22 \pm 2.45^{\mathrm{ab}}$ & $4.46 \pm 0.19$ & $2.67 \pm 0.11^{b}$ & $4.98 \pm 0.12^{b}$ & $111.31 \pm 2.55^{\mathrm{a}}$ \\
\hline $160 \mathrm{~km}$ & $105.00 \pm 0.08^{\mathrm{a}}$ & $2.80 \pm 0.18$ & $3.70 \pm 0.14$ & $0.08 \pm 0.004^{b}$ & $185.60 \pm 2.79^{b}$ & $4.87 \pm 0.23$ & $2.75 \pm 0.08^{b}$ & $5.20 \pm 0.15^{b}$ & $105.65 \pm 1.79^{a}$ \\
\hline $240 \mathrm{~km}$ & $104.58 \pm 0.10^{b}$ & $3.12 \pm 0.24$ & $3.56 \pm 0.14$ & $0.11 \pm 0.009^{a}$ & $196.07 \pm 3.77^{\mathrm{a}}$ & $5.25 \pm 0.23$ & $3.33 \pm 0.15^{\mathrm{a}}$ & $5.81 \pm 0.17^{\mathrm{a}}$ & $99.16 \pm 2.09^{b}$ \\
\hline \multicolumn{10}{|c|}{ Crating densities (birds/crate) } \\
\hline Low & $104.70 \pm 0.09^{b}$ & $2.99 \pm 0.27$ & $3.52 \pm 0.15^{\mathrm{a}}$ & $0.09 \pm 0.009$ & $179.67 \pm 1.24^{c}$ & $4.62 \pm 0.19$ & $2.82 \pm 0.09$ & $5.47 \pm 0.15$ & $98.04 \pm 1.87^{c}$ \\
\hline Medium & $104.91 \pm 0.12^{\mathrm{ab}}$ & $3.04 \pm 0.26$ & $3.49 \pm 0.13^{\mathrm{ab}}$ & $0.08 \pm 0.007$ & $190.68 \pm 2.38^{b}$ & $4.77 \pm 0.18$ & $2.94 \pm 0.13$ & $5.38 \pm 0.19$ & $105.66 \pm 2.31^{b}$ \\
\hline High & $105.16 \pm 0.09^{a}$ & $3.18 \pm 0.22$ & $3.41 \pm 0.14^{b}$ & $0.09 \pm 0.010$ & $200.54 \pm 3.72^{\mathrm{a}}$ & $5.20 \pm 0.30$ & $2.98 \pm 0.18$ & $5.13 \pm 0.13$ & $112.42 \pm 1.99^{a}$ \\
\hline \multicolumn{10}{|c|}{$p$-value } \\
\hline Distance & $<0.0001$ & 0.3825 & 0.0169 & 0.0381 & 0.0123 & 0.0573 & 0.0008 & 0.0007 & $<.0001$ \\
\hline Density & 0.0050 & 0.8643 & 0.8284 & 0.7216 & $<.0001$ & 0.1827 & 0.6295 & 0.2638 & $<.0001$ \\
\hline Interaction & 0.6605 & 0.7236 & 0.1476 & 0.6708 & 0.0984 & 0.8964 & 0.7742 & 0.8551 & 0.2614 \\
\hline
\end{tabular}

acc Means in a column with no common superscript differ significantly at $p \leq 0.05$.

'Values are least square mean \pm standard error

T3: Triiodothyronine, T4: Thyroxine, temp: temperature

Crating density: Low $=10$ birds/crate $\left(0.050 \mathrm{~m}^{2} / \mathrm{bird}\right), 12 \mathrm{birds} / \mathrm{crate}\left(0.042 \mathrm{~m}^{2} / \mathrm{bird}\right)$, and $15 \mathrm{birds} / \mathrm{crate}\left(0.033 \mathrm{~m}^{2} / \mathrm{bird}\right)$. 
were not affected by different crating densities (Table 2). It is well established that thyroid hormones status correlates with body weight and energy expenditure (Fox et al., 2008). These hormones influence key metabolic pathways that control energy balance by regulating energy storage and expenditure (Cheng et al., 2010). The activation of the thyroid will convert T4 into T3 to regulate metabolism (Mullur et al., 2014). In accordance, the transportation of broiler at low crating density resulted in an increase in T4 concentration (Table 2) to help sustain body temperature during winter transportation.

Significantly higher glucose concentration in birds transported for $240 \mathrm{~km}$ compared to rest of the treatments were observed (Table 2). Birds transported for $80 \mathrm{~km}$ had higher glucose concentration than those transported for $160 \mathrm{~km}$ (Table 2). Blood glucose has been considered as cellular fuel and studies have reported an elevation in plasma glucose concentration with the increase in transportation length or stress (Kent \& Ewbank, 1986), primarily due to glycogen breakdown in the liver (Mayes, 1996). Similarly, Yalçin \& Güler (2012) also reported a significant increase in blood glucose concentration with the increase in transportation distance $(65-165 \mathrm{~km})$ in a comprehensive study of 27 flocks (eliminating the effect of seasons). In accordance, Scope et al. (2002) also reported a significant increase in blood glucose concentration in racing pigeons after $3 \mathrm{~h}$ transportation. An increase in the serum glucose contents was also observed with the increase in number of birds per crate (Table 2). The increase in blood glucose levels with the increase in crating density could be due to reduced utilization of glucose at higher crating densities (Zhao et al. 2012). The birds kept at higher crating densities have relatively higher microclimate temperature due to the accumulation of metabolic heat, thereby they showed less struggle for maintaining temperature at low ambient temperature i.e., up to $-18^{\circ} \mathrm{C}$ (Watts et al., 2011). Similarly, some studies also reported a decrease in blood glucose at low ambient temperature (up to $-14^{\circ} \mathrm{C}$ ) (Dadgar et al., 2012) and during winter season $\left(16-18^{\circ} \mathrm{C}\right)$ as compared to summer season (28$32{ }^{\circ} \mathrm{C}$ ) in Turkey (Yalçin et al., 2004).

No differences $(p>0.05)$ in serum total protein contents could be observed in birds after different transportation distance and under different crating densities (Table 2). In accordance with the present study, Sarkar et al. (2013) also reported no effect of transportation distance on total proteins contents when compared with a non-transported treatment group at $24 \pm 0.5{ }^{\circ} \mathrm{C}$ and $62 \%$ relative humidity. In a study on pheasants, Suchy et al. (2007) also reported non-significant difference in the total protein contents between low or high crating densities. While Voslarova et al. (2011) also reported no effect of different crating durations on total protein contents. Serum Albumin contents were higher $(p<0.05)$ in birds transported for $240 \mathrm{~km}$ as compared to those transported for 80 and $160 \mathrm{~km}$ (Table 2). The increase in albumin contents could be due to dehydration associated with longer journeys (Ghanem et al., 2008). Similarly, other studies (Yalçin et al., 2004; Yalçin \& Güler, 2012) have also reported an increase in blood albumin contents after an increase in transportation distance under various temperatures in Turkey.

Serum uric acid contents were significantly higher in birds transported for $240 \mathrm{~km}$ compared to those transported for 80 and $160 \mathrm{~km}$. No difference in uric acid contents were observed between 80 and $160 \mathrm{~km}$ transportation. Similarly, uric acid contents were not affected in different crating densities (Table 2). Uric acid has been reported as one of the major antioxidants in body; an increase in its concentration can be attributed with stress (Simoyi et al., 2002; Hartman et al., 2006). While Sturkie (2000) suggested that the circulating uric acid is a measure for protein catabolism in birds. As it was already discussed that the low-temperature transportation triggers gluconeogenesis, which converts amino acids to glucose and produces uric acid as a waste product, thus resulting in an increase in the uric acid concertation in longer transported (240 km) broilers (Siegel \& Van Kampen, 1984; Malheiros et al., 2003). Reviews regarding the effect of winter transportation on uric acid concentration is scarce. Some studies reported an average increase in uric acid contents in different seasons and transportation under different crating densities was also reported in many studies previously (Yalçin et al., 2004; Delezie et al., 2007). Similarly, Elsayed (2014) also reported a significant increase in uric acid with transportation, but within transportation distances of $15-150 \mathrm{~km}$ the differences remained non-significant. Similarly, no effect of crating and transportation of broiler were observed on uric acid contents (Sarkar et al., 2013).

Serum triglyceride (TGL) contents were found to be higher in birds transported for low and medium distances, whereas significant reduction in TGL levels was observed in longer $(240 \mathrm{~km}$ ) transported birds (Table 2). Moreover, the birds subjected to transportation with the low crating density had low levels of TGL as compared to those transported at higher stocking 
densities (Table 2). Probably, winter transportation triggers metabolic heat production to maintain body temperature and results in hypoglycemia and decrease in TGL contents with the increase in transportation distance (Strawford et al., 2011; Vošmerová et al., 2010; Elsayed, 2014). Moreover, the length of feed withdrawal due to an increase in the length of the journey also caused negative energy balance and stress in birds during transportation that triggers the glycogen breakdown (Nijdam et al., 2005). In accordance with the present study, Vošmerová et al. (2010) also reported a significant increase in TGL contents from 10 to $70 \mathrm{~km}$ but after that, the TGL contents decreased significantly. The differences in both studies could be attributed to the use of three temperatures in previous studies while in the present study the birds were transported at low temperatures only. Similarly, studies conducted in India (Sarkar et al., 2013) and Egypt (Elsayed, 2014) also reported a significant decrease in TGL contents in broiler subjected to transportation as compared to the control group. Moreover, Voslarova et al. (2011) also reported a significant decrease in triglyceride contents with the increase in crating time up to 2 h. However, the study was conducted at relatively higher temperatures than the present study. Most of the studies related to transportation distance and its effect on blood biochemical profile were conducted in countries with mild or hot temperature whilst the data regarding effect of different transportation distance and crating densities on blood biochemical profile during winter season is scarce.

The economic analysis showed transportation of 10 birds per crate for $240 \mathrm{~km}$ resulted in the maximum losses followed by those transported for 240 and $160 \mathrm{~km}$ with 12 and 10 birds per crate respectively (Table 3). Transportation for $80 \mathrm{~km}$ distance showed the least losses compare to those transported for 160 and $240 \mathrm{~km}$. Regarding crating densities, placing 15 birds per crate for 160 and 240 transportation distance showed lower losses compared to placing 10 and 12 birds per crate for the same distance. However, in broiler transported for $80 \mathrm{~km}$, keeping 10 birds per crate resulted in the least losses while losses increased with the increase in the number of birds per crate, but the difference between 12 and 15 birds per crate was marginal (Table 3). The table also showed that, excluding carcass (\%), birds transported for $80 \mathrm{~km}$ with 15 birds per crate crating density showed the least losses during the winter season. These findings can be important from a middleman or transporter perspective, who only transport broilers from farm to processing plants in Pakistan.

Table 3 - Economic evaluation of broiler transportation for variable distances at different crating densities during winter season in terms of Rupees (Rs.) in Pakistani currency (PKR) and US dollars (US \$).

\begin{tabular}{|c|c|c|c|c|c|c|c|c|c|}
\hline \multirow{3}{*}{$\begin{array}{l}\text { Distance }(\mathrm{km}) \\
\text { Crating densities (birds per crate) }\end{array}$} & \multicolumn{9}{|c|}{ Treatments } \\
\hline & \multicolumn{3}{|c|}{$80 \mathrm{~km}$} & \multicolumn{3}{|c|}{$160 \mathrm{~km}$} & \multicolumn{3}{|c|}{$240 \mathrm{~km}$} \\
\hline & 15 & 12 & 10 & 15 & 12 & 10 & 15 & 12 & 10 \\
\hline Fuel used (Liter) approx. & 16.00 & 16.00 & 16.00 & 32.00 & 32.00 & 32.00 & 48.00 & 48.00 & 48.00 \\
\hline Total Fuel cost (Rs. PKR) & 1440 & 1440 & 1440 & 2880 & 2880 & 2880 & 4320 & 4320 & 4320 \\
\hline A: Per bird fuel cost (Rs. PKR) & 0.37 & 0.46 & 0.56 & 0.74 & 0.93 & 1.11 & 1.11 & 1.39 & 1.67 \\
\hline Live weight losses (\%) & 1.56 & 2.05 & 2.35 & 1.71 & 2.92 & 3.01 & 2.68 & 3.91 & 4.37 \\
\hline Cost: Per kg liveweight (Rs. PKR) & 95.00 & 95.00 & 95.00 & 95.00 & 95.00 & 95.00 & 95.00 & 95.00 & 95.00 \\
\hline B: Loss in terms of shrinkage (Rs. PKR) & 1.48 & 1.95 & 2.23 & 1.62 & 2.77 & 2.86 & 2.55 & 3.71 & 4.15 \\
\hline Mortality & 0.00 & 0.00 & 0.00 & 0.00 & 0.00 & 1.00 & 0.00 & 0.83 & 2.00 \\
\hline Weight loss on the basis of mortality & 0.00 & 0.00 & 0.00 & 0.00 & 0.00 & 0.02 & 0.00 & 0.01 & 0.04 \\
\hline C: Loss in terms of mortality (Rs. PKR) & 0.00 & 0.00 & 0.00 & 0.00 & 0.00 & 2.25 & 0.00 & 1.87 & 4.50 \\
\hline Carcass \% & 64.78 & 65.09 & 66.34 & 64.96 & 64.92 & 64.44 & 64.32 & 64.25 & 64.03 \\
\hline Total Cost of meat (Rs. 180 per kg market rate) (Rs. PKR) & 209.9 & 210.9 & 214.9 & 210.5 & 210.3 & 208.8 & 208.4 & 208.2 & 207.5 \\
\hline D: Losses on the basis of carcass shrinkage (Rs. PKR) & 5.05 & 4.05 & 0.00 & 4.47 & 4.60 & 6.16 & 6.54 & 6.77 & 7.48 \\
\hline Total Losses (Rs. PKR) $(A+B+C+D)$ & 6.91 & 6.46 & 2.79 & 6.84 & 8.30 & 12.38 & 10.20 & 13.74 & 17.80 \\
\hline Loss in terms of US\$ @ Rs 155 per $\$$ & 0.04 & 0.04 & 0.02 & 0.04 & 0.05 & 0.08 & 0.07 & 0.09 & 0.11 \\
\hline
\end{tabular}

\section{CONCLUSION}

The current study demonstrated that transportation of broiler is associated with economic losses due to live body weight shrinkage, mortality and bruising of the carcass. $80 \mathrm{~km}$ transportation with 15 birds per crate resulted in lower live losses, however, distance up to $160 \mathrm{~km}$ during the winter season also showed comparable results. Transportation of broilers also resulted in a disturbance in blood metabolites levels, but it did not result in irregularity of body physiological homeostasis till $160 \mathrm{~km}$ of transportation. 
Effect of Broiler Crating Density and Transportation

Distance on Preslaughter Losses and Physiological

Response During the Winter Season in Punjab,

Pakistan

\section{REFERENCES}

Aarif O, Mahapatra PS, Yatoo MA, Dar SA. Impact of cold stress on physiological, hormonal and immune status in male and female broad breasted white turkeys. Journal of Stress Physiology and Biochemistry 2013;9(3):54-60

Ali MS, Kang GH, Joo ST. A review: Influences of pre-slaughter stress on poultry meat quality. Asian-Australasian Journal of Animal Sciences 2008;21(6):912-916

Bianchi M, Petracci M, Cavani C. Effects of transport and lairage on mortality, live weight loss and carcass quality in broiler chickens. Italian Journal of Animal Science 2008;4(Supl 2):516-518.

Brown SN, Warriss PD, Nute GR, Edwards JE, Knowles TG. Meat quality in pigs subjected to minimal preslaughter stress. Meat Science 1998;49(3):257-265

Burkholder KM, Thompson KL, Einstein ME, Applegate TJ, Patterson $J A$. Influence of stressors on normal intestinal microbiota, intestinal morphology, and susceptibility to Salmonella enteritidis colonization in broilers. Poultry Science 2008;87(9):1734-1741.

Cadenas E, Davies KJ. Mitochondrial free radical generation, oxidative stress, and aging. Free Radical Biology and Medicine 2000;29(3-4):222-230.

Caffrey NP, Dohoo IR, Cockram MS. Factors affecting mortality risk during transportation of broiler chickens for slaughter in Atlantic Canada. Preventive Veterinary Medicine 2017;147(1):199-208.

Carlyle WWH, Guise HJ, Cook P. Effect of time between farm loading and processing on carcase quality of broiler chickens. Veterinary Record 1997;141(14):364

Chauvin C, Hillion S, Balaine L, Michel V, Peraste J, Petetin I, et al. Factors associated with mortality of broilers during transport to slaughterhouse. Animals 2011;5(2):287-293

Cheng SY, Leonard JL, Davis PJ. Molecular aspects of thyroid hormone actions. Endocrine Reviews 2010;31(2):139-170.

Dadgar S, Crowe TG, Classen HL, Watts JM, Shand PJ. Broiler chicken thigh and breast muscle responses to cold stress during simulated transport before slaughter. Poultry Science 2012;91(6):1454-1464.

Delezie E, Swennen Q, Buyse J, Decuypere E. The effect of feed withdrawal and crating density in transit on metabolism and meat quality of broilers at slaughter weight. Poultry Science 2007;86(7):1414-1423.

Doktor J, Połtowicz L. Effect of transport to the slaughterhouse on stress indicators and meat quality of broiler chickens. Annals of Animal Science 2009;9(3):307-317.

Ekstrand C. An observational cohort study of the effects of catching method on carcase rejection rates in broilers. Animal Welfare 1998;7(1):87-96.

Elrom K. Handling and transportation of broilers-welfare, stress, fear and meat quality. Part IV: Handling of broilers. Israel Journal of Veterinary Medicine 2000;55(1):121-125.

Elsayed MA. Effects of length of shipping distance and season of the year temperature stress on death rates and physiological condition of broilers on arrival to slaughterhouse. Journal of Nuclear Technology in Applied Science 2014;2(4):453-463.

Farsaie A, Carr LE, Wabeck CJ. Mechanical harvest of broilers. Transactions of the ASAE 1983;26(6):1650-1653.

Fazio E, Ferlazzo A. Evaluation of stress during transport. Veterinary Research Communication 2003;27(Supl 1):519-524.

Fletcher DL. Poultry meat quality. World's Poultry Science Journal 2002;58(2):131-145.
Fox CS, Pencina MJ, D'Agostino RB, Murabito JM, Seely EW, Pearce EN, et al. Relations of thyroid function to body weight: cross-sectional and longitudinal observations in a community-based sample. Archives of Internal Medicine 2008;168(6):587-592.

Ghanem AM, Jaber LS, Abi-Said M, Barbour EK, Hamadeh SK. Physiological and chemical responses in water-deprived Awassi ewes treated with vitamin C. Journal of Arid Environments 2008;72(3):141-149.

Gregory NG. How climatic changes could affect meat quality. Food Research International 2010;43(7):1866-1873.

Hadwan MH, Abed HN. Data supporting the spectrophotometric method for the estimation of catalase activity. Data in Brief 2016;6(1):194-199.

Hartman S, Taleb SA, Geng T, Gyenai K, Guan X, Smith E. Comparison of plasma uric acid levels in five varieties of the domestic turkey, Meleagris gallopavo. Poultry Science 2006;85(10):1791-1794.

Hunter RR, Mitchell MA, Carlisle AJ. Wetting of broilers during cold weather transport: A major source of physiological stress? British Poultry Science 1999:40(Suppl 1):48-49.

Ismail IB, Al-Busadah KA, El-Bahr SM. Oxidative stress biomarkers and biochemical profile in broilers chicken fed zinc bacitracin and ascorbic acid under hot climate. American Journal of Biochemistry and Molecular Biology 2013;3(2):202-214

Jacobs L, Delezie E, Duchateau L, Goethals K, Tuyttens FA. Broiler chickens dead on arrival: Associated risk factors and welfare indicators. Poultry Science 2017;96(2):259-265

Kent JE, Ewbank R. The effect of road transport on the blood constituents and behaviour of calves. II. One to three weeks old. British Veterinary Journal 1986;142(2):131-140.

Kim DH, Yoo YM, Kim SH, Jang BG, Park BY, Cho SH, et al. Effect of the length of feed withdrawal on weight loss, yield and meat color of broiler. Asian-Australasian Journal of Animal Science 2007;20(1):106111.

Knezacek TD, Olkowski AA, Kettlewell PJ, Mitchell MA, Classen HL. Temperature gradients in trailers and change in broiler rectal and core body temperature during winter transportation in Saskatchewan. Canadian Journal of Animal Science 2010;90(3):321-330

Malheiros RD, Moraes VMB, Collin A, Decuypere E, Buyse J. Free diet selection by broilers as influenced by dietary macronutrient ratio and corticosterone supplementation. 1. Diet, selection, organ weights and plasma metabolites. Poultry Science 2003;82(1):123-131.

Mayes PA. Gluconeogenesis and control of the blood glucose. In: Murray RK, Granner DK, Mayer PA, Rodwell VW, editors. Harper's biochemistry. $24^{\text {th }}$ ed. Stamford: Appleton and Lange; 1996.

Mazanowski A. Factors affecting the efficiency of rearing broiler chickens, Cz. IV. Polish Drobe 1997;5(1):2-4

Mitchell MA, Kettlewell PJ. Physiological stress and welfare of broiler chickens in transit: Solutions not problems! Poultry Science 1998;77(12):1803-1814.

Moran Jr ET, Bilgili SE. Influence of Broiler live haul on carcass quality and further processing yields. Journal of Applied Poultry Research 1995;4(1):13-22.

Mullur R, Liu YY, Brent GA. Thyroid hormone regulation of metabolism. Physiological Reviews 2014;94(2):355-382.

Nijdam E, Delezie E, Lambooij E, Nabuurs MJ, Decuypere E, Stegeman JA Feed withdrawal of broilers before transport changes plasma hormone and metabolite concentrations. Poultry Science 2005:84(7):11461152 


\section{Pakistan}

Ondrašovičová O, Saba L, Šmirkjáková S, Vargová M, Ondrašovič M, Matta $S$, et al. Effects of vehicle-road transport on blood profile in broiler chickens. Medycyna Weterynaryjna 2008;64(3):292-293.

Phuong HN, Greene E, Donoghue A, Huff G, Clark FD, Dridi S. A new insight into cold stress in poultry production. Advances in Food Technology and Nutritional Sciences 2016;2(1):1-2.

Qi J, Zhang Y, Zhou Z, Habiba U. Parameters of physiological responses and meat quality in poultry subjected to transport stress. Biological Systems 2017;6(1):175

Sarkar P, Ghosh S, Batabyal S, Chatterjee S. Biochemical stress responses of broiler chickens during transport. Indian Journal of Animal Research 2013;47(1):29-34.

SAS Institute. SAuser's guide: satistics. Release 9.4. Cary; 2013.

Savenije B, Lambooij E, Gerritzen MA, Venema K, Korf J. Effects of feed deprivation and transport on preslaughter blood metabolites, early postmortem muscle metabolites, and meat quality. Poultry Science 2002;81(5):699-708

Scope A, Filip T, Gabler C, Resch F. The influence 350 of stress from transport and handling on hematologic and clinical chemistry blood parameters of racing pigeons (Columba livia domestica). Avian Diseases 2002;46(1):224-229

Siegel HS, Van Kampen M. Energy relationships in growing chickens given daily injection of corticosterone. British Poultry Science 1984;25(4):4714785 .

Silva JAO, Simoes GS, Rossa A, Ida El, Shimokomaki M. Preslaughter transportation and shower management on broiler chicken dead on arrival (DOA) incidence. Semina. Ciências Agrárias 2011;32(2):795800.

Simoyi MF, Van Dyke K, Klandorf H. Manipulation of plasma uric acid in broiler chicks and its effect on leukocyte oxidative activity. American Journal of Physiology-Regulatory, Integrative and Comparative Physiology 2002;282(3):791-796.

Slota C, Chi A, Chen G, Bevans M, Weng NP. Norepinephrine preferentially modulates memory CD8 T cell function inducing inflammatory cytokine production and reducing proliferation response to activation. Brain Behavior and Immunity 2015;46:168-179.

Strawford ML, Watts JM, Crowe TG, Classen HL, Shand PJ. The effect of simulated cold weather transport on core body temperature and behavior of broilers. Poultry Science 2015;90(11):2415-2424.

Sturkie PD. Avian physiology. $4^{\text {th }}$ ed. New York: Springer Verslag; 2000.

Suchy P, Bedanova I, Vecerek V, Voslarova E, Pistekova V, Chloupek P, et al. Effect of transport stress and floor space reduction on selected biochemical indices in common pheasant (Phasianus colchicus). Archiv fur Geflugelkunde 2007;71(1):56-61.
Tukey JW. The problem of multiple comparisons. In: Braun H. The collected works of John W. Tukey. Multiple comparisons. New York; Chapman and Hall; 1953. v.8.

Vecerek V, Grbalova S, Voslarova E, Janackova B, Malena M. Effects of travel distance and the season of the year on death rates of broilers transported to poultry processing plants. Poultry Science 2006;85(11):1881-1884.

Vieira FMC, Silva IJO, Barbosa Filho JAD, Vieira AMC, Broom DM Preslaughter mortality of broilers in relation to lairage and season in a subtropical climate. Poultry Science 2011;90(10):2127-2133.

Vieira FMC, Silva IJO, Barbosa Filho JAD, Vieira AMC. Reducing preslaughter losses of broilers: crating density effects under different lairage periods at slaughterhouse. Journal of Animal Behaviour and Biometeorology 2013;1(1):1-6

Voslarova E, Chloupek P, Vosmerova P, Chloupek J, Bedanova I, Vecerek $V$. Time course changes in selected biochemical indices of broilers in response to pre transport handling. Poultry Science 2011;90(10):21442152

Vošmerová P, Chloupek J, Bedanova I, Chloupek P, Kruzikova K, Blahova $J$, et al. Changes in selected biochemical indices related to transport of broilers to slaughterhouse under different ambient temperatures. Poultry Science 2010;89(12):2719-2725.

Warriss PD, Pagazaurtundua A, Brown SN. Relationship between maximum daily temperature and mortality of broilers chickens during transport and lairage. British Poultry Science 2005;46(6):647-656.

Watts JM, Graff LJ, Strawford ML, Crowe TG, Burlinguette NA, Classen HL, et al. Heat and moisture production by broilers during simulated cold weather transport. Poultry Science 2011;90(9):1890-1899.

Weeks CA. Poultry handling and transport. In: Grandin T, editor. Livestock handling and transport. $4^{\text {th }}$ ed. Colorado: CABl; 2014. p.174-192.

Whiting T, Mairead ED, Rasali DP. Warm weather transport of broiler chickens in Manitoba. II. truck management factors associated with death loss in transit to slaughter. Canadian Veterinary Journal 2007:48(2):148-154.

Yalçin S, Güler HC. Interaction of transport distance and body weight on preslaughter stress and breast meat quality of broilers. British Poultry Science 2012;53(2):175-182

Yalçin S, Özkan S, Oktay G, Çabuk M, Erbayraktar Z, Bilgili SF. Age-related effects of catching, crating, and transportation at different seasons on core body temperature and physiological blood parameters in broilers. Journal of Applied Poultry Research 2004;13(4):549-560.

Zhao JP, Bao J. Wang XJ, Jiao HC, Song ZG, Lin H. Altered gene and protein expression of glucose transporter 1 underlies dexamethasone inhibition of insulin-stimulated glucose uptake in chicken muscles. Journal of Animal Science 2012:90(12):4337-434 
